\title{
Weaving a Destiny: Portrait of Cultural Survival in Dagestan
}

\section{Lorraine Ross}

"You are guests." It is a phrase which is at the heart of the Caucasian culture, and one which my Moscovite companion and I heard repeatedly from the various Dagestinians, with whom we stayed during the summer. It is a phrase which provides honor to the family with whom one is staying and at the same time it elicits a profound sense of duty on their part to provide for the protection and well being of guests. This attitude gave me access to peoples lives within some of the small Caucasus mountain villages and allowed me to begin to examine the link between Dagestan peoples and their artistic activities.

In Makachkala, the capital of Dagestan, as in any small city, I experienced a mix of cultures. Their individual identity and practice is revealed through the production of varied cultural artifacts. I had an opportunity to see the collective works and then move to the more specific sources. In the second largest city of Dagestan, Derbent, we visited the famous carpet bazaar. There, carpets of varying size hung along part of the old Derbent fortress wall. Vendors without a place to hang them lay them across the tops of cars, or sprawled them across the sidewalk. Eager to sell the three or four tapestries they each had, the information they provided us on the village source, helped us to determine where to go to investigate further the making of the carpets and tapestries.

It is the Tabasaran people who are most renowned in Dagestan for their weaving skills. Living high in the mountains they continue to pass along accumulated tradition and understanding to each new. generation. Their physical space reflects adaptations and beliefs through time and like other ethnic groups they have products which resonate with their identity. In making such objects they renew their community identity, habits, customs and life rhythms. This is the foundation of the community constitutive narratives which I hoped to begin to understand.

The Tabasaran administrative center marked a transition between modemity and tradition and was the first point of meeting a large number of Tabasaran villagers. At the outset, I experienced an event that highlighted the Tabasarans sense of humor, and support of each other.

In the late afternoon upon arrival of a large truck with low racks, everyone clambered on from all sides until there was no standing room. Suddenly, a blue decorated Russian trunk is brought alongside the truck along with a large water jug. I thought it was not possible to make room for these and yet suddenly a sea of hands reaches up as the trunk rises up and 
flows along towards the front of the crowd. Somehow they found room for this item amongst all the people. Just as quickly, a child sweeps up the side passed from hand to hand until she reaches where she should go. It is an amazing scene of camaraderie and purpose. Everything and everyone seem to be included. It's simply understood.

As we set off gaining constantly in altitude, the sharp narrow turns make us reel, fall off balance, and pile up against each other. The sea of flesh miraculously rights itself without losing someone over the side. Moments of entertainment come when men on horseback implicitly challenge our vehicle to a race. The crowd yells, "Davai, dava!" (Go ahead, do it) as at a sport. Laughter, cheers and a few whistles go up as the rider is successful in spurring on his steed past the truck on the narrow road.

Stopping only momentarily at a few villages, the strange ride lasts about one and a half hours after which we find ourselves in a village of about 200 families, deep in the heart of the Tabasaran region. We had tacitly agreed to go with the veterinarian, whom we met while waiting for the truck. $\mathrm{He}$ brought us before a greenish blue wooden gate that pushed inwards to reveal an enclosed living space. Surrounding the outside of the house and yard with some sort of high enclosure right up to the roadway is typical of the Northern Caucasus life; an influence of Sufi Moslem in the area. Inside one often finds some sort of garden. Here it is primarily potatoes and onions, about the only crops that really do well at such elevation. The house is old and worn but once inside it appears quite comfortable. Ascending the staircase up to the living quarters they show us a room where we can place our bags. All along the hallway space, carpets are laid covering most of the floor and walls.

Our room is also heavily embellished with carpets. Over my bed hangs a traditional carpet with some Turkish influence. Nearby there is the sign of a more contemporary changing aesthetic. For on one smaller carpet is the image of a popular Azerbaijanian singer. In the largeguest room, we either dine alone or withour host, but never with the women of the family. This area is also generously decorated with carpets. A flood of reds, blues and greens greet the eye. A small one foot piece done in memory of our host's mother, hangs high up near the ceiling as are most ancestral portraits in the Caucasus. As in our sleeping area, there is another large pile of carpets and blankets. I have come to understand that these items which are heaped up are a sign of richness. They are not for show. Usually they are covered by some white cloth but, of course, one can still see the height of the pile. Such collections are fairly common in the mountain villages for they also serve as part of a dowry system. When a daughter marries, part of the collection will be sent to another family, whereas if a son marries the collection is likely to grow. 
We find our host's wife in the main room. She rocks her most recent child while sitting on a large heavy sheөpskin. We join her sitting momentarily on the typical low wooden Caucasus chairs where they usually lay a small carpet. A loom that rests behind her, occupies a large section of the room. The wool is dyed by hand and the balls hang from the top. A pattem wrapped in plastic for protection is inserted within some of the strands in the loom. She has completed about six inches and tells us it takes about two months for her to complete it if she works at it all the time but it's something she usually does during colder weather. It is a precise work. She has drawn out her pattern as she wants it, not made by anyone else and yet, it becomes clear that these carpets are of a certain Tabasaran style, for as we visit other groups of people the carpets are quite different.

Life is difficult in these mountain villages. The strong Moslemic influence makes life especially difficult for women. They are generally responsible for everything within the household but often do other duties as well. For example, women in the villages often carried huge loads of grass cut by hand for the animals to eat while in the village. They also carried water on their backs. Water was generally a very precious item in most of the villages. They take care of the children and here in the Caucasus villages they tend to have large families. The family with whom we stayed had nine children, only one of whom was a girl. It meant that only one child would help our hostess serve, not only her spouse, but all the younger boys.

Women are up at the crack of dawn to begin work, usually herding the animals out of the enclosure sending them up to the mountain hills. Cattle, chickens and sheep are the livestock here, with the long wool of the sheep fundamental to the weaving process. Every step is done by hand; cleaning, carding, dying, spinning of wool. They like to use acrylic fibers when obtainable; it is simply less work.

The kombinat or collective provides an interesting counterpoint to the weaving done at home. Our first visit created a great stir of excitement, for we are from the outside and many of these women will not have the opportunity to see life beyond their own village. I went up and down the two long rows of looms where women are in pairs or occasionally three working on a carpet. They place the thread, hammer it down and then faster than the eye can follow, work magic with the thread as each one must be knotted. A sudden shift of wool color, and the same rhythmic stroke sweeps across the loom. They can do a large carpet in a month. For the women here it is one of the only kinds of work available in the village.

The kombinat area and the teaching and sharing of weaving skills within the home, become times for sharing life's problems and successes. Each person's beliefs and attitudes, personal history and community history play a role in the making of their cultural artifacts. It is that interrelationship 
between Tabasaran life and art which begs further inquiry, further understanding and it is that relationship which I hope to continue to explore upon my return to the ancient mountain villages of Dagestan.

153

Marilyn Zurmuehlen's Working Papers In Art Education 1994-1995 